\title{
Prognostic value of tissue plasminogen activator (tPA) in patients with epithelial ovarian cancer undergoing chemotherapy
}

\author{
Justyna Teliga-Czajkowska', Jacek Sienko², Katarzyna Jalinik ${ }^{3}$, \\ Roman Smolarczyk ${ }^{4}$, Krzysztof Czajkowski² \\ ${ }^{1}$ Department of Obstetrics and Gynecology Didactics, Medical University of Warsaw, Warsaw, Poland \\ ${ }^{2} 2$ nd Department of Obstetrics and Gynecology, Medical University of Warsaw, Poland \\ ${ }^{3}$ Department of Gynecologic Oncology, The Maria Sklodowska-Curie Memorial Cancer Centre and Institute of Oncology, \\ Warsaw, Poland \\ ${ }^{4}$ Department of Gynecological Endocrinology, Medical University of Warsaw, Poland
}

\begin{abstract}
Objectives: Tissue plasminogen activator (tPA) is a key enzyme for fibrin degradation and the proteolytic defense against formation of the thrombotic endothelial deposits. tPA is involved in carcinogenesis but its exact role in tumor biology is not very well understood and a prognostic value of tPA remains ambiguous in different cancers. The aim of the study was to assess the prognostic value of plasma tPA in patients with epithelial ovarian cancer (EOC) in the course of the first line chemotherapy. Material and methods: the study covered 60 patients with EOC who underwent the $1^{\text {st }}$ line chemotherapy. Plasma tPA was assessed at onset, after 3 and 6 cycles of chemotherapy. The groups were stratified according to tPA level at onset of chemotherapy (low tPA group $<6.5 \mathrm{mg} / \mathrm{L}, \mathrm{N}=37$ and high tPA group $>6.5 \mathrm{mg} / \mathrm{L}, \mathrm{N}=23$ ). Survival analysis was repeated for the cut-off of tPA level at $6.5 \mathrm{mg} / \mathrm{L}$ and $5.1 \mathrm{mg} / \mathrm{L}$ after 3 and 6 cycles.

Results: Only subjects with $\mathrm{tPA}>6.5 \mathrm{mg} / \mathrm{L}$ at onset of chemotherapy had a significantly lower probability of a 5-year survival $(34.8 \%$ vs. $72.7 \%, \mathrm{P}<0.006)$ and lower chance for disease free survival within 5 years $(39.3 \%$ vs. $72.7 \%, \mathrm{P}<0.014)$. tPA $<6.5 \mathrm{mg} / \mathrm{L}$ plasma level evaluated at onset of chemotherapy was an independent marker of better overall survival $(\mathrm{RR}=0.44,95 \% \mathrm{Cl}=0.19-0.98)$ but not disease-free survival.

Conclusions: Plasma tPA may serve as a marker of survival if assessed at onset of the first line chemotherapy in patients with ovarian cancer.

Key words: tissue plasminogen activator; tPA; epithelial ovarian cancer; chemotherapy; overall survival; disease free survival
\end{abstract}

\section{INTRODUCTION}

Hemostatic markers are predictors for both thrombosis and hemorrhage. Malignancy enhances the process of fibrin formation and degradation. Local blood clotting is a process strictly associated with cancer - both platelet aggregates and fibrin depositions are found in tumors during histopathological investigations. It is known that hypercoagulability promotes thromboembolic events in cancer with frequency much higher than in benign conditions [1]. Cancer associated thrombosis (CAT) can be linked to oncogenic lesions that account for the onset and progression of malignant disease [2]. Abnormal results of hemeostatic laboratory tests change with cancer progression, which confirms the impact of tumor on blood clotting [3]. As the connection between fibrinolysis and metastasis is established, different fibrinolytic biomarkers are investigated with the aim of foreseeing a prognosis. Two types of plasminogen activators are found in plasminogen activator system - tissue type plasminogen activator (tPA) and urokinase type plasminogen activator (UPA). They both can turn inactive plasminogen to active plasmin. tPA is present in both normal and malignant tissues and is mainly involved in the conversion of plasminogen to plasmin during blood clot dissolution, while uPA, which is mainly associated with malignancy, 
plays a role in proteolysis during cell migration and tissue remodeling [4]. Cell migration is increased by promotion of tPA and uPA mediated proteolytic cleavage of plasminogen to generate plasmin. That subsequently affects breakdown of basement membrane to facilitate cell migration $[5,6]$.

tPA is considered a key enzyme in fibrin degradation and is crucial for the proteolytic defense against formation of the thrombotic endothelial deposits. However, tPA is also produced by epithelial cells, fibroblasts, and macrophages. The role of tPA in tumor biology is not well understood. In breast cancer contradictory results have been reported: high tumor tissue content of tPA was observed to be associated with good prognosis, whereas high content of the TPA:PAI-1 complex was associated with shorter disease-free survival (DFS) and overall survival (OS) [7]. In ovarian cancer large amounts of fibrin are deposited within and around ovarian tumors secondary to the release of tissue factor from tumor cells and macrophages. Fibrin may enhance tumor cell adhesion to endothelial and mesothelial surfaces. The fibrin deposition leads to the activation of plasminogen mediated by tPA which results in degradation of matrix by plasmin [8]. As an evidence of the above process, fibrin degradation products are detectable in high concentrations in peripheral blood and ascitic fluid [9]. Experimental data on mechanism of action of TPA encouraged scientist to evaluate its role as a prognostic factor in EOC. There are some studies which showed that a high expression of tPA in tumor tissue is a negative predictor of survival $[10,11]$. However, very little is known about possible predictive meaning of plasma tPA especially at various stages of EOC treatment [12].

\section{Objectives}

The aim of our study was to investigate the prognostic significance of plasma tPA in patients with epithelial ovarian cancer who underwent the first line chemotherapy.

\section{MATERIALS AND METHODS}

Ethics statement

The study was conducted under the approval of the local Bioethics Committee at Medical University of Warsaw. All subjects have provided written informed consent.

\section{Patients and samples}

The study was carried out between 2011 and 2018. 60 patients with a diagnosis of epithelial ovarian cancer (EOC), who had previously undergone surgery, were enrolled into the study at the onset of the first line adjuvant chemotherapy. Chemotherapy regimen included 6 cycles of intravenous paclitaxel and carboplatin. Blood samples were taken from the patients at the onset of chemotherapy, and again after 3 and 6 cycles of chemotherapy. tPA, fibrinogen,
D-dimer and antithrombin III (AT III) were assessed in blood plasma. Besides prothrombin time (PT), activated partial thromboplastin time (APTT), and international normalized ratio (INR) test was performed. The IMUBIND ${ }^{\circledR}$ tPA ELISA (Sekisui Diagnostics, LLC, USA) test was used for the quantitative measurement of tPA in plasma.

Response to chemotherapy was assessed according to RECIST 1.1 criteria [13]. OS was defined as time from the start of treatment until death from any cause and DFS was defined as time from the start of treatment until disease progression or death (according to Food and Drug Administration guidance) [14]. The clinicopathological data were obtained from medical records.

Two groups of patients were identified according to tPA level at the onset of chemotherapy: tPA $<6.5 \mathrm{mg} / \mathrm{L}$ group and tPA $>6.5 \mathrm{mg} / \mathrm{L}$ group. The choice of the tPA cut-off level was based on analysis of tPA level distribution. The mean follow-up time from the initial treatment which included surgery was $57.0 \pm 22.9$ months ( 2.6 to 87.6 months).

\section{Statistical analysis}

The results were presented as mean \pm standard deviation (SD). Significant statistical differences between groups were assessed applying the chi-square test, exact Fisher test or Student's $t$ test. The Kaplan-Meier method was employed to plot survival curves, and differences in survival were compared using the log-rank test. The Cox regression model was used to ascertain the value of independent prognosis for patients with epithelial ovarian cancer. $\mathrm{P}<0.05$ was considered statistically significant.

\section{RESULTS}

The low tPA ( $<6.5 \mathrm{mg} / \mathrm{L}$ ) group consisted of 37 patients and the high tPA group ( $>6.5 \mathrm{ng} / \mathrm{mL}$ ) was represented by 23 subjects. The clinicopathological characteristic of the groups is presented in Table 1.

No differences between the groups were observed regarding patient age, tumor stage and grade, and histological type of malignancy. Only the rate of overweight/obese patients (BMI $>25 \mathrm{~kg} / \mathrm{m} 2 /$ ) was significantly higher in the high tPA group $(P=0.006)$. The results of the first-line chemotherapy are presented in Table 2.

No differences in response to chemotherapy were observed in the low and high tPA group regardless of the way the response was stratified (complete remission - partial remission - stabilization - progression or any response vs. no response).

We evaluated tPA plasma level in both groups after 3 and 6 cycles of chemotherapy and found that tPA concentration was significantly higher in the high tPA group throughout the whole $1^{\text {st }}$ line of chemotherapy. PT and INR were other coagulation parameters significantly elevated from the on- 


\begin{tabular}{|c|c|c|c|}
\hline & $\begin{array}{l}\text { Low tPA group } \\
(<6.5 \mathrm{mg} / \mathrm{L}) \\
\mathrm{N}=37\end{array}$ & $\begin{array}{l}\text { High tPA group } \\
(>6.5 \mathrm{mg} / \mathrm{L}) \\
\mathrm{N}=23\end{array}$ & $\mathbf{P}$ \\
\hline Age [years] & $53.4 \pm 10.6$ & $59.1 \pm 12.5$ & 0.06 \\
\hline $\mathrm{BMI}=<25\left[\mathrm{~kg} / \mathrm{m}^{2}\right]$ & $11(29.7 \%)$ & $16(69.6 \%)$ & 0.006 \\
\hline $\begin{array}{l}\text { Histological type n [\%] } \\
\text { - Serous } \\
\text { - Endometrioid } \\
\text { - Clear cell } \\
\text { - } \text { Mucinous }\end{array}$ & $\begin{array}{l}15(40.6 \%) \\
12(32.4 \%) \\
8(21.6 \%) \\
2(5.4 \%)\end{array}$ & $\begin{array}{l}14(73.7 \%) \\
1(5.2 \%) \\
4(21.1 \%) \\
0(0 \%)\end{array}$ & 0.06 \\
\hline $\begin{array}{l}\text { Stage n (\%) } \\
\text { I } \\
\text { II } \\
\text { III } \\
\text { IV }\end{array}$ & $\begin{array}{l}12(32.4 \%) \\
4(10.8 \%) \\
21(56.8 \%) \\
0(0 \%)\end{array}$ & $\begin{array}{l}6(26.1 \%) \\
1(4.3 \%) \\
15(65.2 \%) \\
1(4.4 \%)\end{array}$ & 0.44 \\
\hline $\begin{array}{l}\text { Grade n (\%) } \\
1 \\
2 \\
3\end{array}$ & $\begin{array}{l}9(24.3 \%) \\
17(46.0 \%) \\
11(29.7 \%)\end{array}$ & $\begin{array}{l}6(26.1 \%) \\
4(17.4 \%) \\
13(56.5 \%)\end{array}$ & 0.06 \\
\hline $\begin{array}{l}\text { Early cancer (FIGO I-II) } \\
\text { Advanced cancer } \\
\text { (FIGO III-IV) }\end{array}$ & $\begin{array}{l}16(43.2 \%) \\
21(56.8 \%)\end{array}$ & $\begin{array}{l}7(30.4 \%) \\
16(69.6 \%)\end{array}$ & 0.47 \\
\hline
\end{tabular}

Table 2. Correlation between tPA serum level and the clinical results of the first line chemotherapy. Values are mean +/- SD or present a number [\%] of cases in groups. Student's t test or exact Fisher test were applied, respectively

\begin{tabular}{|l|l|l|l|}
\hline & $\begin{array}{l}\text { Low tPA group } \\
\mathbf{1}(\mathbf{6 . 5} \mathbf{~ m g / L )} \\
\mathbf{N = 3 7}\end{array}$ & $\begin{array}{l}\text { High tPA group } \\
(>\mathbf{6 . 5} \mathbf{~ m g / L )} \\
\mathbf{N}=\mathbf{2 3}\end{array}$ & $\mathbf{P}$ \\
\hline $\begin{array}{l}\text { Response to } \\
\text { treatment } \\
\text { - Complete } \\
\text { remission }\end{array}$ & $33(89.2 \%)$ & $17(73.9 \%$ & 0.25 \\
- Partial remission & $2(5.4 \%)$ & $1(4.4 \%)$ & \\
- Stabilization & $0(0 \%)$ & $1(4.4 \%)$ & \\
- Progression & $2(5.4 \%)$ & $4(17.3 \%)$ & \\
$\begin{array}{l}\text { Any response } \\
\text { vs. progression }\end{array}$ & $35(0.94 .6 \%)$ & $19(82.6 \%)$ & 0.29 \\
\hline
\end{tabular}

set till the end of chemotherapy when compared between the low and high tPA group (Tab. 3).

\section{Survival analyses}

We plotted Kaplan-Meier curves (Fig. 1) to analyze OS and DFS according to tPA level at different stages of chemotherapy.

Subjects with tPA $>6.5 \mathrm{mg} / \mathrm{L}$ at the onset of chemotherapy had a significantly lower probability of a 5 -year survival $(34.8 \%$ vs. $72.7 \%, \mathrm{P}<0.006)$ and chance for disease free survival within 5 years was significantly lower in this group (39.3\% vs. $72.7 \%, \mathrm{P}<0.014)$, (Fig. 1). We
Table 3. The results of coagulation tests in the low and high tPA group at the onset, after 3 and 6 cycles of chemotherapy. Values present mean +/- SD. Student's t test

\begin{tabular}{|l|l|l|l|}
\hline & $\begin{array}{l}\text { Low tPA group } \\
\text { (<6.5 mg/L) }\end{array}$ & $\begin{array}{l}\text { High tPA group } \\
(>6.5 \mathrm{mg} / \mathrm{L})\end{array}$ \\
$\mathrm{N}=37$ & $\mathrm{P}=37$ \\
\hline
\end{tabular}

At onset of chemotherapy

\begin{tabular}{l|l|l|l}
\hline PT [s] & $11.32 \pm 0.75$ & $11.93 \pm 1.24$ & 0.02 \\
\hline APTT [s] & $28.26 \pm 2.93$ & $28.67 \pm 4.04$ & 0.65 \\
D-dimer [mg/L] & $2.08 \pm 4.66$ & $2.80 \pm 2.28$ & 0.49 \\
Fibrinogen [g/L] & $3.52 \pm 0.76$ & $3.64 \pm 0.84$ & 0.56 \\
\hline After 3 cycles of chemotherapy & & \\
\hline tPA [mg/L] & $3.57 \pm 1.08$ & $9.83 \pm 7.75$ & 0.0007 \\
PT [s] & $10.94 \pm 0.63$ & $11.44 \pm 0.85$ & 0.03 \\
APTT [s] & $27.92 \pm 2.97$ & $28.01 \pm 3.31$ & 0.92 \\
D-dimer [mg/L] & $0.67 \pm 0.47$ & $1.27 \pm 1.45$ & 0.06 \\
Fibrinogen [g/L] & $3.51 \pm 0.59$ & $3.66 \pm 0.73$ & 0.47 \\
\hline After 6 cycles of chemotherapy & & \\
\hline tPA [mg/L] & $4.13 \pm 1.64$ & $7.45 \pm 4.35$ & 0.002 \\
PT [s] & $11.01 \pm 0.70$ & $11.48 \pm 0.86$ & 0.06 \\
APTT [s] & $27.30 \pm 2.80$ & $27.88 \pm 3.21$ & 0.52 \\
D-dimer [mg/L] & $1.49 \pm 3.73$ & $2.17 \pm 3.61$ & 0.56 \\
Fibrinogen [g/L] & $3.22 \pm 0.64$ & $3.46 \pm 0.62$ & 0.24
\end{tabular}

repeated the analysis after 3 and 6 cycles of chemotherapy for the cut-off of tPA level at $6.5 \mathrm{mg} / \mathrm{L}$ and $5.1 \mathrm{mg} / \mathrm{L}$ (the level of $5.1 \mathrm{mg} / \mathrm{L}$ corresponded the best with the results presented in Table 3). However, we found no significant differences in DFS and OS in all those groups after 3 and 6 cycles of chemotherapy (Fig. 2 and 3 ).

Univariate analysis showed that a high tPA plasma level at the onset of chemotherapy, advanced tumor stage, tumor grade 2 or 3 and residual disease were associated with worse OS and DFS. BMI $>25 \mathrm{~kg} / \mathrm{m}^{2}$ was only related to shorter DFS (Tab. 4).

Multivariate analysis revealed that tPA plasma level at onset of chemotherapy was an independent marker of OS but not DFS (Tab. 5). Tumor stage and grade were also independent predictors of OS.

\section{DISCUSSION}

The pathogenesis of hemostatic disorders in cancer is complex and reflects an interaction of coagulation and fibrinolytic system, vascular endothelium, leukocytes, and platelets. Circulating biomarkers of hemostasis have been extensively studied to predict cancer outcomes along with predicting the thrombotic risk. Plasminogen activators released from cancer cells lead to degradation of basement membrane proteins and extracellular matrix and facilitate cancer cell invasion into surrounding tissues and blood stream. It has been shown that tPA plays a major role in invasion in case of different types of highly aggressive tumors such as melanoma, glioblastoma, pancreatic, breast and endometrial cancer [15-19]. Majority of authors investigated 

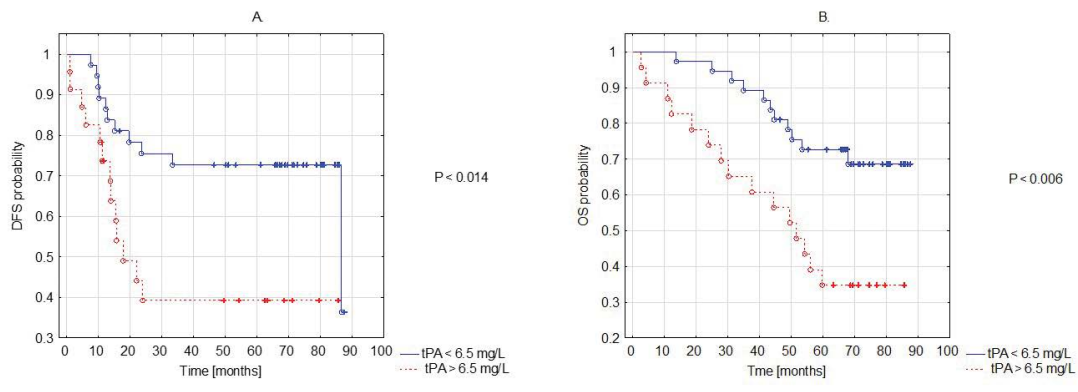

Figure 1. Kaplan-Meier analysis of disease-free survival (DFS) and overall survival (OS) according to tPA level at onset of chemotherapy. A. - DFS, $6.5 \mathrm{mg} / \mathrm{L}<\mathrm{tPA}<6.5 \mathrm{mg} / \mathrm{L} ;$ B. $-\mathrm{OS}, 6.5 \mathrm{mg} / \mathrm{L}<\mathrm{tPA}<6.5 \mathrm{mg} / \mathrm{L}$, Log rank test
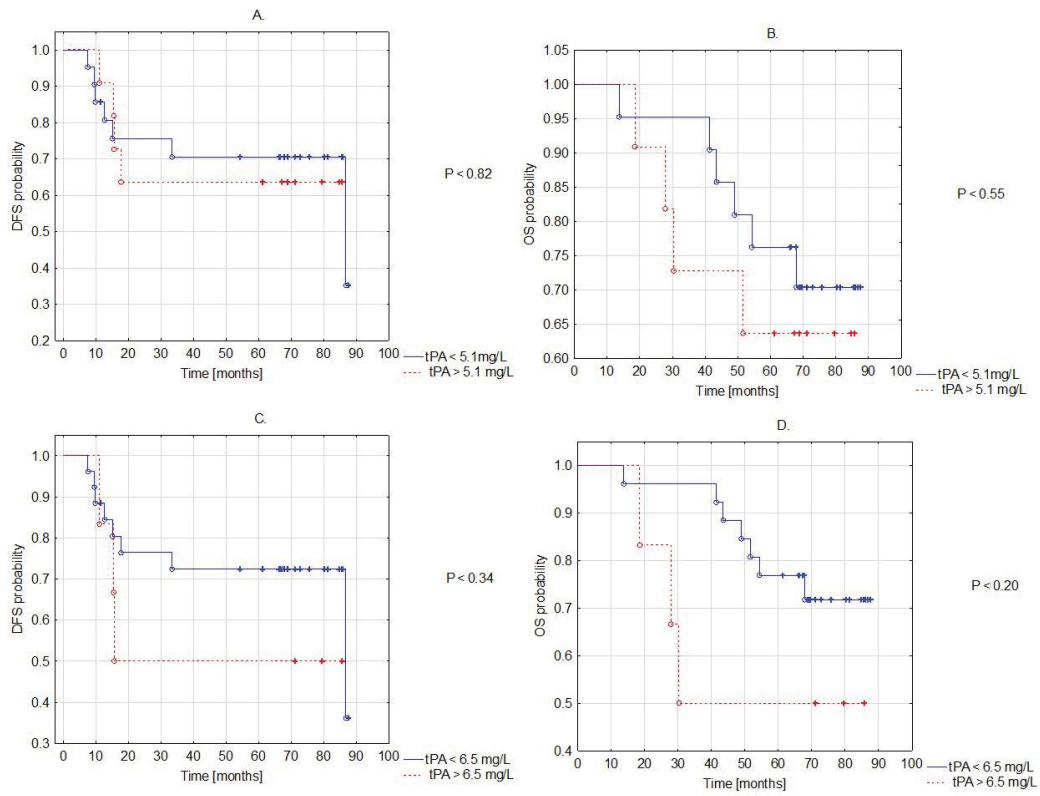

Figure 2. Kaplan-Meier analysis of disease-free survival (DFS) and overall survival (OS) according to tPA level after 3 cycles of chemotherapy. A. DFS, 5.1 $\mathrm{mg} / \mathrm{L}<\mathrm{tPA}<5.1 \mathrm{mg} / \mathrm{L} ;$ B. $-\mathrm{OS}, 5.1 \mathrm{mg} / \mathrm{L}<\mathrm{tPA}<5.1 \mathrm{mg} / \mathrm{L} ;$ C. $-\mathrm{DFS}, 6.5 \mathrm{mg} / \mathrm{L}<\mathrm{tPA}<6.5 \mathrm{mg} / \mathrm{L} ;$ D. $-O \mathrm{OS}, 6.5 \mathrm{mg} / \mathrm{L}<\mathrm{tPA}<6.5 \mathrm{mg} / \mathrm{L} ;$ Log rank test

tissue tPA levels and obtained data came from the removed tumor at the time of surgery [15-17, 19]. In our opinion this approach has got a weakness: tumor state in vivo is much more complex than in cell culture. Neoplastic and nonneoplastic cells manifest migratory and invasive properties, linked to the cancer cell-induced process of tissue reconstruction. Expression of the plasminogen activation system differs between various tumors originating from the same tissue or from the same organ, depending on the extent of their histological differentiation [13]. In neoplastic cells the degradation of the extracellular matrix proteins is facilitated by excessive expression of t-PA. In many forms of carcinoma increased expression of fibrinolytic biomarkers is associated with significantly shorter survival. In acute nonlymphocytic leukemias, poor outcome correlates with high t-PA levels
[14]. In the study by Chernicky et al. on breast cancer, low expression of tissue tPA correlated with better prognosis and longer DFS [15].

We decided to investigate the prognostic significance of plasma tPA in patients with epithelial ovarian cancer who underwent the first line chemotherapy. We found only one study which investigated prognostic value of plasma levels of selected fibrinolytic parameters in ovarian cancer [12]. Ho et al. showed that blood tPA did not differ in patients with malignant tumors, benign gynecological diseases and healthy controls. The expression of tissue tPA was significantly lower inside the tumor compared with adjacent ovarian tissue but there was no significant correlation between plasma and tissue concentration of tPA. In our study plasma concentration of tPA $<6.5 \mathrm{mg} / \mathrm{L}$ 

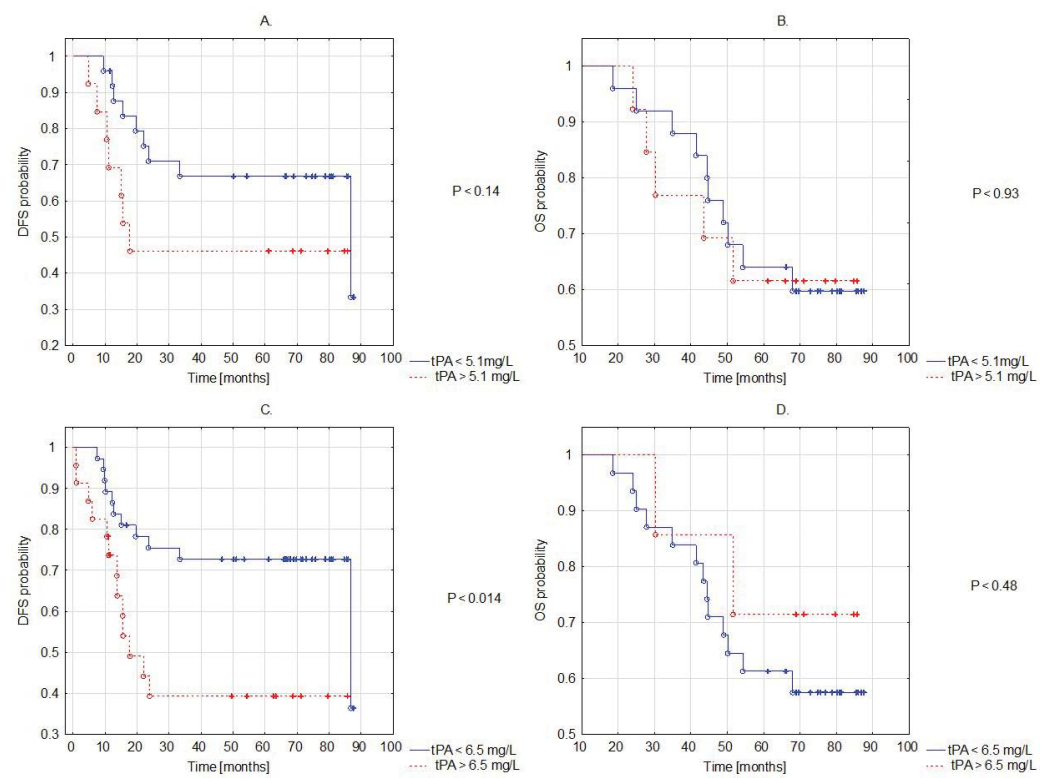

Figure 3. Kaplan-Meier analysis of disease-free survival (DFS) and overall survival (OS) according to tPA level after 6 cycles of chemotherapy. A. - DFS, $5.1 \mathrm{mg} / \mathrm{L}<\mathrm{tPA}<5.1 \mathrm{mg} / \mathrm{L} ;$ B. - OS, $5.1 \mathrm{mg} / \mathrm{L}<\mathrm{tPA}<5.1 \mathrm{mg} / \mathrm{L} ;$ C. — DFS, $6.5 \mathrm{mg} / \mathrm{L}<\mathrm{tPA}<6.5 \mathrm{mg} / \mathrm{L} ;$ D. $-\mathrm{OS}, 6.5 \mathrm{mg} / \mathrm{L}<\mathrm{tPA}<6.5 \mathrm{mg} / \mathrm{L} ; \mathrm{Log} \mathrm{rank}$ test

Table 4. Univariate analysis of factors associated with OS and DFS. The Cox regression model. RR presents relative risk of death or relapse/progression, respectively

\begin{tabular}{|l|l|l|l|l|l|l|}
\hline \multirow{2}{*}{ Variable } & \multicolumn{2}{l}{ OS } & \multicolumn{3}{l|}{ DFS } \\
\cline { 2 - 7 } & $\mathbf{R R}$ & $\mathbf{9 5 \%}$ Cl & $\mathbf{P}$ & $\mathbf{R R}$ & $\mathbf{9 5 \%}$ Cl & $\mathbf{P}$ \\
\hline tPA $<6.5 \mathrm{mg} / \mathrm{L}$ vs. $>6.5 \mathrm{mg} / \mathrm{L}$ & 0.34 & $0.15-0.73$ & 0.006 & 0.35 & $0.15-0.80$ & 0.01 \\
\hline FIGO I-II vs. III-IV & 0.09 & $0.02-0.36$ & 0.0009 & 0.12 & $0.03-0.50$ & 0.005 \\
\hline Grade 1 vs. 2-3 & 0.29 & $0.13-0.65$ & 0.003 & 0.43 & $0.19-0.98$ & 0.04 \\
\hline Residual disease & 0.25 & $0.11-0.54$ & 0.0005 & 0.20 & $0.09-0.47$ & 0.0002 \\
\hline BMI $<25 \mathrm{~kg} / \mathrm{m} 2$ vs. $\geq 25 \mathrm{~kg} / \mathrm{m} 2$ & 0.55 & $0.25-1.20$ & 0.13 & 0.36 & $0.15-0.84$ & 0.02 \\
\hline Serous vs. non-serous tumor & 0.61 & $0.25-1.46$ & 0.27 & 0.70 & $0.29-1.71$ & 0.43 \\
\hline Age $\leq 60$ years vs. $>60$ years & 0.38 & $0.50-2.15$ & 0.93 & 0.94 & $0.40-2.20$ & 0.88 \\
\hline
\end{tabular}

Table 5. Multivariate Cox regression analysis of factors associated with OS and DFS. RR presents relative risk of death or relapse/progression, respectively

\begin{tabular}{|c|c|c|c|c|c|c|}
\hline \multirow{2}{*}{ Variable } & \multicolumn{3}{|l|}{ os } & \multicolumn{3}{|l|}{ DFS } \\
\hline & RR & $95 \% \mathrm{Cl}$ & $\mathbf{P}$ & $\mathbf{R R}$ & $95 \% \mathrm{Cl}$ & $\mathbf{P}$ \\
\hline Low vs. high tPA & 0.44 & $0.19-0.98$ & 0.044 & 0.59 & $0.25-1.40$ & 0.23 \\
\hline FIGO 1-2 vs. 3-4 & 0.12 & $0.03-0.55$ & 0.006 & 0.26 & $0.05-1.27$ & 0.09 \\
\hline Grade 1 vs. 2-3 & 0.33 & $0.15-0.76$ & 0.009 & 0.57 & $0.24-1.34$ & 0.20 \\
\hline Residual disease & 0.52 & $0.23-1.18$ & 0.117 & 0.41 & $0.16-1.02$ & 0.06 \\
\hline $\mathrm{BMI}<25$ vs. $\geq 25$ & & & & 0.61 & $0.25-1.48$ & 0.28 \\
\hline
\end{tabular}

at the onset of chemotherapy was associated with longer OS and DFS. Our decision to determine plasma tPA just before the beginning of chemotherapy was based on the fact that this is the time when discussion with a patient about prognosis takes place, adjuvant therapy is outlined and the need for reliable prognostic factors is indisputable. For the same reason we decided to repeat our analysis after 3 and 6 cycles of chemotherapy. We chose two cut-off levels 
of plasma tPA: $6.5 \mathrm{mg} / \mathrm{L}$ and $5.1 \mathrm{mg} / \mathrm{L}$. There were no significant differences neither in OS nor in DFS in all analyzed settings. These results have proven the clinical prognostic usefulness of plasma tPA determination only at the onset of the first line chemotherapy, not later. There is no data in the literature that could be compared with our findings. The above-mentioned Ho et al. didn't give any information on the time of collecting plasma samples, whether it was in any way connected with surgery or chemotherapy [12]. We also performed Cox regression analysis which proved that plasma tPA level of $6.5 \mathrm{mg} / \mathrm{L}$ at the onset of chemotherapy was a marker of short OS and DFS in univariate analysis and an independent marker of poor OS in multivariate analysis. This result makes tPA a good candidate for a clinical biomarker of EOC prognosis.

It is important to underline that our low and high plasma tPA groups were homogenic in terms of patients age, tumor stage, grade and histological type of malignancy as well as response to chemotherapy. Only the rate of overweight and obese patients was significantly higher in the high plasma tPA group. The impact of BMI on hemostatic markers has been widely discussed, although data concerning tPA is conflicting [20-22]. Smith et al. found that plasma tPA concentration positively correlated with triglyceride levels and BMI and negatively with HDL cholesterol level whereas Morgan et al. didn't confirm that relationship [23, 24]. Our univariate analysis revealed that BMI $>25 \mathrm{~kg} / \mathrm{m}^{2}$ didn't increase the risk of death but was associated with shorter DFS. In multivariate analysis BMI was not an independent factor of OS and DFS.

We also specifically looked at the clotting global tests as their availability in clinical settings is widely known [11, 25-27]. Mean PT was statistically longer in the high tPA group but didn't exceed the upper reference value at the onset and after 3 and 6 cycles of chemotherapy. Our findings were consistent with the study by Tas et al. where prolonged PT was associated with poorer $\mathrm{OS}(\mathrm{P}=0.03)$ and progression free survival (PFS) $(P=0.04)$ [28].

Independent prognostic value of the tumor stage, tumor grade and residual disease associated with poor OS in our study is consistent with many other studies regarding EOC $[7,17,29]$. Lack of significance in DFS comparison may reflect the limitation of our study design which is the sample size.

\section{CONCLUSIONS}

Plasma tPA is an independent marker of survival if assessed at the onset of the first line chemotherapy in patients with ovarian cancer.

\section{Acknowledgments}

The authors thank Pawel Derlatka for help in patient recruitment.

\section{REFERENCES}

1. Timp JF, Braekkan SK, Versteeg HH, et al. Epidemiology of cancer-associated venous thrombosis. Blood. 2013; 122(10): 1712-1723, doi: 10.1182/blood-2013-04-460121, indexed in Pubmed: 23908465.

2. Rak J, Milsom $\mathrm{C}$, Magnus $\mathrm{N}$, et al. Tissue factor in tumour progression. Best Pract Res Clin Haematol. 2009; 22(1): 71-83, doi: 10.1016/j. beha.2008.12.008, indexed in Pubmed: 19285274.

3. Rickles FR, Falanga A. Activation of clotting factors in cancer. Cancer Treat Res. 2009; 148: 31-41, doi: 10.1007/978-0-387-79962-9_3, indexed in Pubmed: 19377917.

4. Jaiswal RK, Varshney AK, Yadava PK. Diversity and functional evolution of the plasminogen activator system. Biomed Pharmacother. 2018; 98: 886-898, doi: 10.1016/j.biopha.2018.01.029, indexed in Pubmed: 29571259.

5. Dutta S, Bandyopadhyay C, Bottero V, et al. Angiogenin interacts with the plasminogen activation system at the cell surface of breast cancer cells to regulate plasmin formation and cell migration. Mol Oncol. 2014; 8(3): 483-507, doi: 10.1016/j.molonc.2013.12.017, indexed in Pubmed: 24457100.

6. Sadagopan S, Veettil MV, Chakraborty S, et al. Angiogenin functionally interacts with p53 and regulates p53-mediated apoptosis and cell survival. Oncogene. 2012;31(46):4835-4847, doi: 10.1038/onc.2011.648, indexed in Pubmed: 22266868.

7. Borgfeldt $C$, Bendahl PO, Fernö $M$, et al. High preoperative plasma concentration of tissue plasminogen activator (tPA) is an independent marker for shorter overall survival in patients with ovarian cancer. Gynecol Oncol. 2003; 91(1): 112-117, indexed in Pubmed: 14529669.

8. Murthi P, Barker G, Nowell CJ, et al. Plasminogen fragmentation and increased production of extracellular matrix-degrading proteinases are associated with serous epithelial ovarian cancer progression. Gynecol Oncol. 2004; 92(1): 80-88, indexed in Pubmed: 14751142.

9. Hafter R, KlaubertW, Gollwitzer R, et al. Crosslinked fibrin derivatives and fibronectin in ascitic fluid from patients with ovarian cancer compared to ascitic fluid in liver cirrhosis. Thromb Res. 1984; 35(1):53-64, indexed in Pubmed: 6474409.

10. Whitley BR, Palmieri D, Twerdi CD, et al. Expression of active plasminogen activator inhibitor-1 reduces cell migration and invasion in breast and gynecological cancer cells. Exp Cell Res. 2004; 296(2): 151-162, doi: 10.1016/j.yexcr.2004.02.022, indexed in Pubmed: 15149846.

11. Bell WR. The fibrinolytic system in neoplasia. Semin Thromb Hemost. 1996; 22(6): 459-478, doi: 10.1055/s-2007-999047, indexed in Pubmed: 9122711.

12. Ho CH, Yuan CC, Liu SM. Diagnostic and prognostic values of plasma levels of fibrinolytic markers in ovarian cancer. Gynecol Oncol. 1999; 75(3): 397-400, doi: 10.1006/gyno.1999.5610, indexed in Pubmed: 10600296.

13. Andreasen PA, Egelund $\mathrm{R}$, Petersen $\mathrm{HH}$. The plasminogen activation system in tumor growth, invasion, and metastasis. Cell Mol Life Sci. 2000; 57(1): 25-40, doi: 10.1007/s000180050497, indexed in Pubmed: 10949579.

14. Menell JS, Cesarman GM, Jacovina AT, et al. Annexin II and bleeding in acute promyelocytic leukemia. N Engl J Med. 1999; 340(13): 994-1004, doi: 10.1056/NEJM199904013401303, indexed in Pubmed: 10099141.

15. Chernicky $\mathrm{CL}$, Yi L, Tan $\mathrm{H}$, et al. Tissue-type plasminogen activator is upregulated in metastatic breast cancer cells exposed to insulin-like growth factor-I. Clin Breast Cancer. 2005; 6(4): 340-348, doi: 10.3816/CBC.2005.n.038, indexed in Pubmed: 16277885.

16. Paciucci $R$, Torà $M$, Díaz VM, et al. The plasminogen activator system in pancreas cancer: role of t-PA in the invasive potential in vitro. Oncogene. 1998; 16(5): 625-633, doi: 10.1038/sj.onc. 1201564, indexed in Pubmed: 9482108.

17. Gershtein ES, Kushlinskii NE. Urokinase and tissue plasminogen activators and their inhibitor PAI-1 in human tumors. Bull Exp Biol Med. 2001; 131(1): 67-72, indexed in Pubmed: 11329087.

18. Sandström $M$, Johansson $M$, Sandström J, et al. Expression of the proteolytic factors, tPA and UPA, PAI-1 and VEGF during malignant glioma progression. Int J Dev Neurosci. 1999; 17(5-6): 473-481, indexed in Pubmed: 10571409.

19. Samulak D, Malinska A, Razik E, et al. A potency of plasminogen activation system in long-term prognosis of endometrial cancer: a pilot study. Eur J Obstet Gynecol Reprod Biol. 2012; 163(2): 193-199, doi: 10.1016/j. ejogrb.2012.03.031, indexed in Pubmed: 22525297.

20. Ridker PM, Vaughan DE, Stampfer MJ, et al. A cross-sectional study of endogenous tissue plasminogen activator, total cholesterol, HDL cholesterol, and apolipoproteins A-I, A-II, and B-100. Arterioscler Thromb. 1993; 13(11): 1587-1592, indexed in Pubmed: 8218099. 
21. Hunt BJ. The effect of BMI on haemostasis: Implications for thrombosis in women's health. Thromb Res. 2017; 151 Suppl 1: S53-S55, doi: 10.1016/S0049-3848(17)30068-3, indexed in Pubmed: 28262235.

22. Samad F, Ruf W. Inflammation, obesity, and thrombosis. Blood. 2013 122(20): 3415-3422, doi: 10.1182/blood-2013-05-427708, indexed in Pubmed: 24092932

23. Smith FB, Lee AJ, Hau CM, et al. Tissue-plasminogen activator, plasminogen activator inhibitor and risk of peripheral arterial disease. Atherosclerosis. 1995; 115(1): 35-43, indexed in Pubmed: 7669086.

24. Morgan ES, Wilson E, Melody T, et al. An observational study of haemostatic changes, leptin and soluble endoglin during pregnancy in women with different BMIs. Blood Coagul Fibrinolysis. 2017; 28(1): 50-55, doi: 10.1097/MBC.0000000000000535, indexed in Pubmed: 26881854.

25. Falanga $A$, Marchetti $M$, Vignoli $A$, et al. Clotting mechanisms and cancer: implications in thrombus formation and tumor progression.
Clin Adv Hematol Oncol. 2003; 1(11): 673-678, indexed in Pubmed: 16258469.

26. Falanga A, Marchetti M, Vignoli A. Coagulation and cancer: biological and clinical aspects. J Thromb Haemost. 2013; 11(2): 223-233, doi: 10.1111/jth.12075, indexed in Pubmed: 23279708.

27. Reddel CJ, Tan CW, Chen VM. Thrombin Generation and Cancer: Contributors and Consequences. Cancers (Basel). 2019; 11(1), doi: 10.3390/cancers11010100, indexed in Pubmed: 30654498.

28. Tas F, Kilic L, Bilgin E, et al. Clinical and prognostic significance of coagulation assays in advanced epithelial ovarian cancer. Int J Gynecol Cancer. 2013; 23(2): 276-281, doi: 10.1097/IGC.0b013e31827b8796, indexed in Pubmed: 23266651.

29. Whitley BR, Palmieri D, Twerdi CD, et al. Expression of active plasminogen activator inhibitor-1 reduces cell migration and invasion in breast and gynecological cancer cells. Exp Cell Res. 2004; 296(2): 151-162, doi: 10.1016/j.yexcr.2004.02.022, indexed in Pubmed: 15149846. 